\title{
Analysis of the APO B R3500Q Mutation and APOE Polymorphism in Taif Saudi Population using Polymerase Chain Reaction- Reveres Hybridization Technique
}

\author{
Nabil Saied Awad* and Adel El-Sayed El-Tarras
}

College of Medicine, Biotechnology and Genetic Engineering Unit, Taif University, Taif, Kingdom Saudi Arabia

\begin{abstract}
This study describes the use of Cardio Vascular Disease (CVD) Strip Assay which based on Polymerase Chain Reaction Reverse Hybridization Technique to study the prevalence of Apo B R3500Q mutation and Apo E genotypes in Taif city Saudi Arabian population. Among 200 unrelated healthy subjects residing in Taif city 5,600 feet above sea level complete absence of Apo B R3500Q mutation was observed. Among six different Apo E genotypes, five genotypes were detected (E3/E3, E4/E4, E2/E3, E2/E4 and E3/E4) with prevalence\% (63, 2.5, 8.5,1 and 25) respectively. The allelic frequencies of Apo $E$ alleles were 0.79 for E3, 0.15 for $E 4$ and 0.048 for E2.Obtained data concluded that, this is the first report about Apo B R3500Q mutation in Saudi Arabia and the absence of it confirmed that this mutation has not reached Saudi Arabia from central Europe which is the common origin of this mutation. Among Apo E genotypes, only E2/E2 genotype was absent while another E2/E3 and E2/E4 genotypes were detected in Taif Saudi population.
\end{abstract}

Keywords: APO B R3500Q; Mutation; APOE; Polymorphism; Reverse Hybridization; PCR

\section{Introduction}

Apolipoprotein B-100 (apo B-100) is a protein molecule consisting of 4560 amino acid residues. It has $500 \mathrm{KD}$ molecular weight and mainly secreted by the liver [1-3].It is the major protein component of the circulating atherogenic low-density lipoprotein (LDL) particle and play a central role in cholesterol transport by its association to LDL particles as a ligand for LDL receptor [4]. ApoB-100 is encoded by a gene that has been localized to the short arm of chromosome 2. This gene consists of 28 introns and 29 exons. The longest coding sequence within the gene is exon 26. More than one half of the apoB-100 protein molecule is coded by this exon $[3,5]$. There have been several mutations identified in the apoB-100 gene leading to premature truncation of protein synthesis or to amino acid substitution within the protein [3]. Such changes can influence the metabolism of plasma lipoprotein and may therefore be important in the development of hyperlipidemia and coronary heart disease [3]. One of the most common single site mutations in the human apoB gene, is ApoB-100 R3500Q (apoBR3500Q) mutation, which resulted from a single nucleotide transition, CGG to CAG, in exon 26 at position 10708 of the apoB gene and leads to amino acid substitution of glutamine for arginine at position 3500 [6,7] results in mild to severe hypercholesterolaemia and an increased risk for early onset atherosclerosis [7]. This mutation reduces the affinity to the LDL receptor by at least $95 \%$ [8] and is the major cause of familial defective ApoB-100 (FDB). Although it is widely accepted that the average population frequency of the R3500Q mutation is about 1:500-1:700 among white populations [9], other results from population studies, as well as data from studies of high risk groups in Europe, show that frequencies vary ranging between $1: 715$ and 1:1250 [10].There is a lack of information about the mutation prevalence in Saudi Arabia population. This is the first study explore this mutation at molecular level among Saudi population.

Apolipoprotein E (apo E) is a structural protein of chylomicrons, very low density lipoprotein (VLDL), intermediate density lipoprotein (IDL) and high-density lipoprotein (HDL) in human plasma [11].

The apo $\varepsilon$ gene is located at chromosome 19q13.2 and is closely linked to the apo C-I/C-II gene complex [12]. It consists of four exons and three introns spanning 3,597 nucleotides and produces a 299 amino acid polypeptide $[12,13]$. It is synthesized primarily in the liver, but other organs and tissues also synthesize apo E, including brain, spleen, kidneys, gonads, adrenals, and macrophages [11].

Apo E plays an important role in the metabolism of cholesterol and triglycerides in human plasma through the uptake of apo E containing lipoprotein by apo B, E (LDL) receptors or by LDL receptor-related protein (LRP) in the liver [11,14-17].

Three common alleles, $\varepsilon 2, \varepsilon 3$ and $\varepsilon 4$ at the apo E gene locus code for three protein isoforms, apo E2, E3, and E4, respectively [18]. Six different genotypes are found by different combinations of these three alleles [19]. Accumulating evidence demonstrates that ApoE alleles are associated with both cardiovascular and Alzheimer's diseases [2125]. The frequency of each APOE isoform varies dramatically with geographical region, race and ethnicity [26]. The aim of the present study was to identify the frequency of (apoBR3500Q) mutation as the first time in Saudi Arabia population and investigate the prevalence of Apolipoprotein E (ApoE) genotypes in Taif Saudi population.

\section{Materials and Methods}

\section{Samples collection}

Blood samples from 200 unrelated healthy Saudi subjects residing in Taif city 5,600 feet above sea level with no cardiovascular disease

${ }^{*}$ Corresponding author: Nabil Saied Awad, College of Medicine, Biotechnology and Genetic Engineering Unit, Taif University, Taif, Kingdom Saudi Arabia, E-mail: nabilfaris151@yahoo.com

Received May 05, 2011; Accepted June 20, 2011; Published June 28, 2011

Citation: Awad NS, El-Tarras AE (2011) Analysis of the APO B R3500Q Mutation and APOE Polymorphism in Taif Saudi Population using Polymerase Chain Reaction- Reveres Hybridization Technique. J Mol Biomark Diagn 2:109. doi:10.4172/2155-9929.1000109

Copyright: ( 2011 Awad NS, et al. This is an open-access article distributed under the terms of the Creative Commons Attribution License, which permits unrestricted use, distribution, and reproduction in any medium, provided the original author and source are credited 
symptoms were randomly collected into EDTA anticoagulant vacutainer tubes. Verbal consent was obtained from all participants prior to blood samples collection and all institutional requirements were met.

\section{DNA extraction, PCR amplification and reverse hybridization}

Analysis of (apoBR3500Q) mutation and Apo E polymorphism was carried out via CVD StripAssay, ViennaLab, Austria (http:// www.viennalab.com) manufacture protocol. The CVD StripAssay is based on polymerase chain reaction (PCR) and subsequent reverse hybridization. CVD StripAssay includes three steps1) DNA extraction 2) PCR amplification with biotinylated primer pairs and 3) hybridization of amplified products with test strips carrying allele-specific oligonucleotide probes immobilized in parallel lines. Bound biotinylated sequences are detected by streptavidin -alkaline phosphatase and color substrates. Briefly PCR amplifications were carried out in two separate reactions A (amplification mix A) and B (amplification mix B) that differ in primers pairs and $5 \mu$ DNA template for each reaction.PCR reactions $A$ and $B$ were carried out with the same thermal profile as follow. Initial step of $94^{\circ} \mathrm{C}$ for $2 \mathrm{~min}$., and followed by 35 cycles of $94^{\circ} \mathrm{C}$ for $15 \mathrm{sec}$., $58^{\circ} \mathrm{C}$ for $30 \mathrm{sec}$. and $72^{\circ} \mathrm{C}$ for $30 \mathrm{sec}$, final extension was at $72^{\circ} \mathrm{C}$ for $3 \mathrm{~min}$. PCR products from reaction $\mathrm{A}$ and $\mathrm{B}$ were mixed together with hybridization buffer, incubated for 5 min at room temperature and hybridized to the detection test strip. Hybridization was accomplished at $45^{\circ} \mathrm{C}$. After series of stringent washes (according to the protocol of provider) the reaction was detected by color development directly on test strip. Results were evaluated from test strips using provided scale included in the kit.

\section{Results}

In order to analyze the ApoB R3500Q mutation among 200 subjects included in the present study, CVD StripAssay was utilized. For each subject one of three possible staining patterns may be

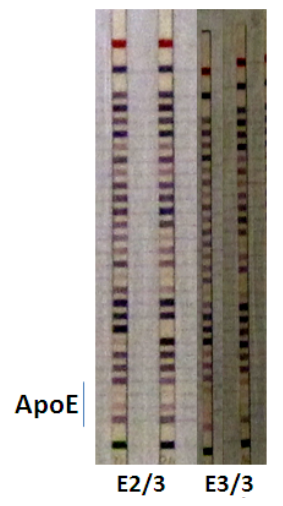

Figure 1: Banding pattern of Test strips (CVD StripAssay) demonstrate two different APO E Genotypes.

\begin{tabular}{|l|l|l|l|l|l|}
\hline \multirow{2}{*}{ Genotype } & \multirow{2}{*}{ No. of subjects } & Prevalence & \multicolumn{4}{|l|}{ Allele Frequency } \\
& & & E2 & E3 & E4 \\
\hline E3/ E3 & 126 & $\mathbf{6 3}$ & & 252 & \\
\hline E4/ E4 & 5 & $\mathbf{2 . 5}$ & & & 10 \\
\hline E2/ E3 & 17 & 8.5 & 17 & $\mathbf{1 7}$ & \\
\hline E2/ E4 & 2 & 1 & $\mathbf{2}$ & & 2 \\
\hline E3/ E4 & 50 & $\mathbf{2 5}$ & & 50 & 50 \\
\hline Total & 200 & & $19(0.048)$ & $319(0.79)$ & $\mathbf{6 2 ( 0 . 1 5 6 )}$ \\
\hline
\end{tabular}

Table1: Prevalence \% of Apo E genotypes and allele frequency. obtained as follow;1)Wild type probe only: Normal genotype (GG) ,2) Wild type and mutant probe: Heterozygous genotype(GA) carrier and 3)Mutant type probe only: Homozygous mutant type(AA). Obtained results indicated that, complete absent of R3500Q mutation between studied subjects was observed. According to CVD StripAssay manual, six different APOE genotypes could be detected (E2/ E2, E3/ E3, E4/ E4, E2/ E3, E3/ E4 and E2/ E4). For each individual only one genotype of possible six genotypes will be obtained. Figure 1 demonstrate example for obtained ApoE genotypes during present study.

Table (1) illustrates resulted genotypes, number and \% prevalence of each genotype in addition allele frequency of three alleles (E2, E3and E4) respectively in Saudi population under this study. Based on obtained staining banding pattern for each test strip of CVD StripAssay, five ApoE genotypes were detected (E3/ E3, E4/ E4, E2/ E3, E3/ E4 and E2/ E4). However homozygous ApoE2/E2 was absent in this studied Saudi population. Among 200 studied individuals, there were $400 \mathrm{ApoE}$ alleles. Out of which 319 (0.79) were E3, 62 (0156) E4 and 19(0.048) E2. Five genotypes were resulted. The most frequent genotype was E3/ E3 with prevalence $\% 63 \%$, while, the lowest frequent genotype was E2/ E4 1\%. E3/E4, E2/E3 and E4/E4 genotypes were detected and theirs Prevalence was $25 \%, 8.5 \%$ and $2.5 \%$ respectively.

\section{Discussion}

After association between R3500Q and FDB and association between apoE polymorphism with cardiovascular disease and cardiovascular disease risk factors was reported, several studies worldwide have been carried out to study the prevalence of apoB100R3500Q mutation and apoE genotypes in different populations and their geographical distributions [7,27-30]. Molecular screening of the ApoE alleles and genotypes using DNA amplification was carried out by CVD StrippAssay. Test strips carrying allele-specific oligonucleotide probe, immobilized in parallel lines, allow hybridization of PCR amplification products and immediate recognition of ApoB100 R3500Q mutation as well as ApoE alleles and genotypes that could be detected after a colour development reaction directly on the test strip. For one patient, one strip is needed [31].

The obtained results indicated that complete absence of apoB R3500Q among studied Saudi population. This result is in agreement with the previous reports which indicated the high frequency of the apoB R3500Q mutation are reported to be clustered in central Europe, and the mutation frequency decreases as one moves east, north, and south west [32]. In Germany, UK and USA, prevalence ranges from $1 / 700$ to $1 / 500[32,33]$. The rate of mutation in California was found to be $0.08 \%$ [34]. The mutation could not be found in Turkish [11,35-36]; Spain [37]; Israiel and Japan [38]; Lebanon [39] and Iranian [40]. The absence of the apoBR3500Q mutation among studied Saudi population also supports the hypothesis of the origin of this mutation which hypothesized that this mutation arose within the Central European region from a common ancestor approximately 7000 years ago and spread across Europe [36,41-42].

In the present study high frequency of E3 allele (79\%) was observed and followed by $15.6 \%$ for E4 and $4.8 \%$ for E2. These results in the same trend with previous results collected from different 12 populations $[28,43]$. Among the resulted five genotypes E3/E3 was the most prevalent genotype (63\%) and the lowest was E2lE4 (1\%) while the prevalence of E3/E4, E2/E3 and E4/E4 genotypes were 25\%,8.5\% and $2.5 \%$ respectively. These genotypes prevalence's are concordant with the results among different population such as Nigerians(44); African Americans [45]; American Indian [46]; Caucasians [47]; Germany 
Citation: Awad NS, El-Tarras AE (2011) Analysis of the APO B R3500Q Mutation and APOE Polymorphism in Taif Saudi Population using Polymerase Chain Reaction- Reveres Hybridization Technique. J Mol Biomark Diagn 2:109. doi:10.4172/2155-9929.1000109

[48]; Finland [49]; France [50]; Italy [51]; Chinese [52]; Japanese [53] and Swedish [18]. In comparison with previously published Saudi studies, there are three published studies demonstrate apoE genotypes prevalence and allele frequencies with general population over 65 years [54]; with normal individuals [55] and with primary glaucoma Saudi patients [19]. All of these studies in agreement with the present study that E3/E3 genotype was the highest prevalent genotype and E3 was the more frequent allele. On the contrary the last studies reported that E2 allele and its different genotypes were absent while in the present study document the detection of this allele and its genotypes.These differences may be due to geographical distribution gradients, high altitude at Taif city, race and/or ethnicity of studied population .The frequency of each APOE isoform varies dramatically with geographical region, race and ethnicity [26-27,56-57]; In Europe [58] found a clear north to south decline in E4 allele frequency but for E3 they found an inverse south to north decreasing gradient and in China (59) when they concluded that there is a conspicuous south to north, but not an east to west gradient for the apoE4 allele in China. Results of the present study similar with those found in other Arabian country such as Gulf Arab population in Kuwait [26]; Tunisia population (60) and Lebanese [43].

In conclusion, among 200 unrelated healthy subjects residing in Taif city in Kingdom Saudi Arabia (KSA) complete absent of ApoBR3500Q was observed. Five genotypes of Apo E (E3/ E3, E4/ E4, $\mathrm{E} 2 / \mathrm{E} 3, \mathrm{E} 3 / \mathrm{E} 4$ and E2/ E4) were detected. E3 was the highest frequent allele (0.79) followed by E4 (.156). E2 allele was detected with allele frequency (.048). Further detailed studies are needed to 1) estimate the prevalence of apoBR3500Q mutation in different KSA locations 2) assess the correlation between presence of E2 allele and geographical distribution, high altitude and/or race and ethnicity background.

\section{References}

1. Elovson J, Jacobs JC, Schumaker VN, Puppione DL (1985) Molecular weights of -apoprotein B obtained from human low-density lipoprotein (apoprotein B-PI) and from rat very low density lipoprotein (apoprotein B-PIII). Biochemistry 24: 1569-1578.

2. Veniant MM, Nielsen LB, Boren J, Young SG (1999) Lipoproteins containing apolipoprotein B-100 are secreted by the heart. Trends Cardiovasc Med 9: 103107

3. Vrablík M, Ceska R, Horínek A (2001) Major apolipoprotein B-100 mutations in lipoprotein metabolism and atherosclerosis. Physiol Res 50:337-343.

4. Brown MS, Goldstein JL (1986) A receptor mediated pathway for cholesterol homeostasis. Science 232: 34-47.

5. Blackhart BD, Ludwig EM, Pierotti VR, Caiati L, Onasch MA, et al. (1986) Structure of the Human Apolipoprotein B Gene. J Biol Chem 261:15364-15367.

6. Innerarity TL, Weisgraber KH, Arnold KS, Mahley RW, Krauss RM, (1987) Familial defective apolipoprotein B100: low density lipoproteins with abnorma receptor binding. Proc Natl Acad Sci USA 84: 6919-6923.

7. Soria LF, Ludwig EH, Clarke HR, Vega GL, Grundy SM, et al. (1989) Association between a specific Apolipoprotein $B$ mutation and familial defective apolipoprotein B100. Proc Natl Acad Sci USA 86:587-591.

8. Maher VM, Gallagher JJ, Myant NB (1993) The binding of very low density lipoprotein remnants to the low density lipoprotein receptor in familial defective apolipoprotein B-100. Atherosclerosis 102:51-61.

9. Rauh G, Keller C, Schuster H, Wolfram G, Zöllner N (1992) Familial defective apolipoprotein B-100: a common cause of primary hypercholesterolemia. Clin Investiq 70:77-84.

10. Hansen PS (1998) Familial defective apolipoprotein B-100. Dan Med Bul 45:370-382.

11. Mahley RW(1988) Apoliporotein E: cholesterol transport protein with expanding role in cell biology. Science 240:622-630.

12. Scott J, Knott TJ, Shaw DJ, Brook JD (1985) Localization of genes encoding apolipoprotein $\mathrm{Cl}, \mathrm{CII}$, and $\mathrm{E}$ to the $\mathrm{p} 13$->cen region of human chromosome 19 Hum Genet 71:144-146.

13. Rall SC, Weisgraber KH, Mahley RW (1982) Human apolipoprotein E The complete amino acid sequence. J Biol Chem 257:4171-4178.

14. Pitas RE, Innerarity TL, Mahley RW (1980) Cell surface receptor binding of phospholipid-protein complexes containing different ratios of receptor-active and -inactive E apoprotein. J Biol Chem 256:5454-5460.

15. Gregg RE, Brewer Jr HB (1988) The role of apolipoprotein E and lipoprotein receptors in modulating the in vivo metabolism of apolipoprotein B-containing lipoproteins in humans. Clin Chem 34:B28-32.

16. Cobb MM, Teitlebaum H, Risch N, Jekel J, Ostfeld A (1992) Influence of dietary fat, apolipoprotein $\mathrm{E}$ phenotype, and sex on plasma lipoprotein levels. Circulation 86:849-857.

17. Coetzee, Gerhard A, van der Westhuyzen, Deneys R (1992) Lipoprotein receptors in perspective. Current Opinion in Lipidology 3:60-68.

18. Eggertsen G, Tegelman R, Ericsson S, Angelin B, Berglund L(1993) Apolipoprotein E Polymorphismin a Healthy Swedish Population: Variation of Allele Frequency with Age and Relation to Serum Lipid Concentrations Clin Chem 39: 2125-2129.

19. Al-Dabbagh NM, Al-Dohayan N, Arfin M, Tariq M (2009) Apolipoprotein E polymorphisms and primary glaucoma in Saudis. Molecular Vision 15:912-919.

20. Bouthillier D, Sing CF, Davignon J (1983) Apolipoprotein E phenotyping with a single gel method: application to the study of informative matings. J. Lipid Res 24: $1060-1069$.

21. Brousseau T, Arveiler D, Cambou JP, Evans AE, Luc G, et al.(1995) Familial defective apolipoprotein B-100 and myocardial infarction. The ECTIM study. Etude Cas-Temoins de l'Infarctus du Myocarde. Atherosclerosis.116: 269-271.

22. Poirier $\mathrm{J}(1999)$ Apolipoprotein $\mathrm{E}$ : a pharmacogenetic target for the treatment of Alzheimer's disease.Mol Diagn 4: 335-341.

23. Poirier J (2000) Apolipoprotein E and Alzheimer's disease a role in amyloid catabolism. Ann N Y Acad Sci 924: 81-90.

24. Mahley RW, Rall SC Jr (2000) Apolipoprotein E: far more than a lipid transport protein. Annu Rev Genomics Hum Genet 1: 507-537.

25. Saunders AM, Trowers MK, Shimkets RA, Blakemore S, Crowther DJ, et al.(2000) The role of apolipoprotein E in Alzheimer's disease: pharmacogenomic target selection. BiochimBiophysActa 1502: 85-94.

26. Al-Shammari S, Fatania H, Al-Radwan R, Akanji AO(2004) Apolipoprotein E polymorphism and lipoprotein levels in a Gulf Arab population in Kuwait : a pilo study. Ann Saudi Med 24: 361-364.

27. Hallman DM, Boerwinkle E, Saha N, Sandholzer C, Menzel HJ, et al.(1991) The Apolipoprotein $\mathrm{E}$ polymorphism: a comparison of allele frequencies and effects in nine populations. Am J Hum Genet 49: 338-349.

28. Eichner JE, Dunn T, Ghazala P, Thompson DM, Kenneth E Stewart et al. (2002) Apolipoprotein E Polymorphism and Cardiovascula Disease: A HuGE Review Am J Epidemiol 155:487-495. Corder EH, Ervin JF, Lockhart E, Szymanski MH, Schmechel DE, et al.(2005) Cardiovascular damage in Alzheimer disease: autopsy findings from the Bryan ADRC. J Biomed Biotechnol 2005: 189-197.

29. Bednarska-Makaruk M, Rodo M, Markuszewski C, Rozenfeld A, Swiderska M et al.(2005) polymorphisms of Apolipoprotein E and Angiotensin-converting enzyme genes and carotid atherosclerosis in heavy drinkers Alcohol Alcohol 40: 274- 282.

30. Jurkovicova D, Goncalvesova E, Sedlakova B, Hudecova S, Fabian J(2006 Is the ApoE Polymorphism Associated with Dilated Cardiomyopathy? Gen PhysiolBiophys25:3-10.

31. Horvath A, Alexey S, Stephen K, Elina K, Iva P, et al.(2001) High frequency of the ApoB-100 R3500Q mutation in Bulgarian hypercholesterolaemic subjects. J Med Genet38:536-540.

32. Brousseau T, Arveiler D, Cambou JP, Evans AE, Luc G, et al. (1995) Familia defective apolipoprotein B-100 and myocardial infarction. The ECTIM study. Etude Cas-Temoins de l'Infarctus du Myocarde. Atherosclerosis 116:269-271.

33. Bersot TP, Russell SJ, Thatcher SR, Pomernacki NK, Mahley RW, et al. (1993) A unique haplotype of the apolipoprotein B-100 allele associated with familia defective apolipoprotein B- 100 in a Chinese man discovered during a study of the prevalence of this disorder. J Lipid Res34:1149-1154. 
Citation: Awad NS, El-Tarras AE (2011) Analysis of the APO B R3500Q Mutation and APOE Polymorphism in Taif Saudi Population using Polymerase Chain Reaction- Reveres Hybridization Technique. J Mol Biomark Diagn 2:109. doi:10.4172/2155-9929.1000109

Page 4 of 4

34. Tamer L, Tanriverdi K, Ercan B, Unlu A, Sucu N, et al. (2004) Apolipoprotein B gene polymorphisms in people in the east Mediterranean area of Turkey. East Mediterr Health J10: 125- 130.

35. Eroglu Z, Selvi N, Kosova B, Biray C, Kumral E,et al. (2008) Absence of apolipoprotein B-3500 mutation in Turkish patients with coronary and cerebrovascular atherosclerosis. Anadolu Kardiyol Derg 8:7-9.

36. Castillo S, Tejedor D, Mozas P, Reyes G, Civeira F, et al. ( 2002) The apolipoprotein B R3500Q gene mutation in Spanish subjects with a clinical diagnosis of familial hypercholesterolemia. Atherosclerosis 165: 127-135.

37. Friedlander Y, Dann EJ, Leitersdorf E (1993) Absence of familial defective apolipoprotein B- 100 in Israeli patients with dominantly inherited hypercholesterolemia and in offspring with parental history of myocardial infarction. Hum Genet 91:299-300.

38. Sabbagh AS, Daher RT, Otrock ZK, Khalek RN, Zaatari GS, et al.(2007) ApoB$100 \mathrm{R} 3500 \mathrm{Q}$ mutation in the Lebanese population: prevalence and historical review of the literature. Mol Biol Rep 34:267-270.

39. Fard-Esfahani $\mathrm{P}$, Mohammadi PT, Khatami S, Zeinali S, Taghikhani M, et al.(2005) Familial defective apoliporrotein b 100:frequency of R3500Q mutation of poliporotein $b$ gene in iranian hypercholesterolemic patients. Acta Medica Iranica 43: 193-196.

40. Myant NB, Forbes SA, Day IN, Gallagher J (1997) Estimation of the age of the ancestral arginine3500-->glutamine mutation in human apoB-100. Genomics 45: 78-87.

41. MiserezAR, Muller PY (2000) Familial defective apolipoprotein B-100: amutation emerged in the Mesolithic ancestors of Celtic peoples? Atherosclerosis 148 : 433-436.

42. Mahfouz RA, Sabbagh AS, Zahed LF, Mahfoud ZR, Kalmoni RF, et al. (2006) Apolipoprotein $\mathrm{E}$ gene polymorphism and allele frequencies in the Lebanese population. Mol Biol Rep 33: 145-149.

43. Howard BV, Gidding SS, Lui K (1998) Association of apolipoprotein E phenotype with plasma lipoproteins in African-American and white young adults: the CARDIA Study. Coronary Artery Risk Development in Young Adults. Am J Epidemiol 148:859-868.

44. Kataoka S, Robbins DC, Cowan LD, Ordovas JM, Schaefer MM, et al. (1996) Apolipoprotein E polymorphism in American Indians and its relation to plasma lipoproteins and diabetes: the Strong Heart Study. Arterioscler Thromb Vasc Biol 16: 918-925.

45. Schaefer EJ, Lamon-Fava S, Johnson S, et al. (1994) Effects of gender and menopausal status on the association of Apolipoprotein $E$ phenotype with plasma lipoprotein levels: results from the Framingham Offspring Study. Arterioscler Thromb Vasc Biol;14:1105-13.

46. Assman G, Schmitz G, Menzel HJ (1984) Apolipoprotein E polymorphism and hyperlipidemia. Clin Chem 30: 641-643.

47. Lehtimäki T, Moilanen T, Viikari J, Akerblom HK, Ehnholm C, et al. (1990) Apolipoprotein $\mathrm{E}$ phenotypes in Finnish youths: a cross-sectional and 6-year follow- up study. J Lipid Res 31: 487-495.

48. Luc G, Bard JM, Arveiler D, Evans A, Cambou JP, et al. (1994) Impact of apolipoprotein $\mathrm{E}$ polymorphism on lipoproteins and risk of myocardial infarction: the ECTIM Study. Arterioscler Thromb14: 1412-1419.

49. Cattin L, Fisicaro M, Tonizzo M, Valenti M, Danek GM et al. (1997) Polymorphism of the apolipoprotein $\mathrm{E}$ gene and early carotid atherosclerosis defined by ultrasonography in asymptomatic adults. Arterioscler Thromb Vasc Biol 17: 91-94.

50. Evans AE, Zhang W, Moreel JFR, Bard JM, Ricard S, et al. (1993 Polymorphisms of the apolipoprotein $B$ and $E$ genes and their relationship to plasma lipid variables in healthy Chinese men. Hum Genet 92: 191-197.

51. Eto M, Watanabe K, Makino I (1989) Increased frequencies of apolipoprotein $\varepsilon 2$ and $\varepsilon 4$ alleles in patients with ischemic heart disease. Clin Genet 36: 183-188.

52. Al-Khedhairy AA (2004) Apolipoprotein E polymorphism as a predictor fo cognitive decline and dementia in the Saudi general population over 65 years. Genetics and Molecular Biology 27: 331-334.

53. Al-Khedhairy AA (2004) Apolipoprotein E polymorphism in Saudis. Molecular Biology Reports 31: 257-260.

54. Siest G, Pillot T, Regis-Bailly A, Leininger-Muller B, Steinmetz J, et al. (1995 Apolipoprotein $\mathrm{E}$ : an important gene and protein to follow in laboratory medicine. Clin Chem 41:1068-1086.

55. Xia Y, Sass C, Shen X, Siest G, Visvikis S (2000) Associations of apolipoprotein $\mathrm{E}$ concentration and polymorphism with lipids and apolipoprotein levels in Chinese from Beijing and Shanghai. Clin Chem Lab Med 38: 655-659.

56. Lucotte G, Loirat F, Hazout S (1997) Pattern of gradient of apolipoprotein E allele *4 frequencies in western Europe. Hum Biol 69: 253-262.

57. Hu P, Qin YH, Jing CX, Lu L, Hu B, et al. (2011) Does the geographical gradient of ApoE4 allele exist in China? A systemic comparison among multiple Chinese populations. Mol Biol Rep 38: 489-494.

58. Jemaa R, Elasmi M, Naouali C, Feki M, Kallel A, et al. (2006) Apolipoprotein $\mathrm{E}$ polymorphism in the Tunisian population:Frequency and effect on lipid parameters. Clin Biochem 39: 816-820. 